\title{
The Effects of Local Food-Based Enteral Nutrition to Improve Nutritional Status of Post-Stroke Patients
}

\author{
Punik Mumpuni Wijayanti ${ }^{4}$ Mawaddah Ar Rochmah ${ }^{1}$ \\ ${ }^{1}$ Department of Neurology, Faculty of Medicine, Public Health and \\ Nursing, Universitas Gadjah Mada, Dr. Sardjito General Hospital, \\ Yogyakarta, Indonesia \\ 2Department of Nutrition and Health, Faculty of Medicine, Public \\ Health and Nursing, Universitas Gadjah Mada, Yogyakarta, \\ Indonesia \\ ${ }^{3}$ Department of Internal Medicine, Faculty of Medicine, Public \\ Health and Nursing, Universitas Gadjah Mada, Dr. Sardjito General \\ Hospital, Yogyakarta, Indonesia \\ ${ }^{4}$ Department of Public Health, Faculty of Medicine, Islamic \\ University of Indonesia, Yogyakarta, Indonesia
}

Ismail Setyopranoto ${ }^{1}$ Susetyowati ${ }^{2}$ Lily Arsanti Lestari ${ }^{2}$ Probosuseno ${ }^{3}$

\begin{abstract}
Address for correspondence Ismail Setyopranoto, MD, PhD, Department of Neurology, Faculty of Medicine, Public Health, and Nursing, Universitas Gadjah Mada, Jalan Kesehatan no.1, Sekip, Yogyakarta, Indonesia (e-mail: ismail.setyopranoto@ugm.ac.id).
\end{abstract}

J Neurosci Rural Pract:2021;12:204-209

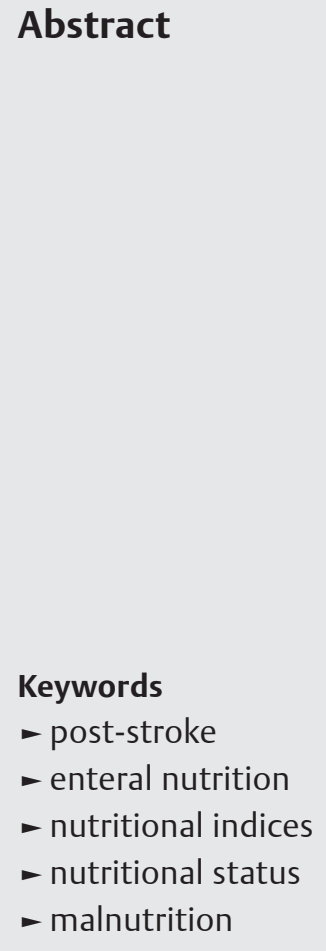

Objective We used local-based enteral formula for post-stroke patients to see its effects on the nutritional status.

Materials and Methods This is an experimental research with a pre- and post-test study design in post-stroke patients. Participants underwent clinical and laboratory examinations to assess their nutritional status before and after the enteral nutrition supplementation. The enteral formula preparation, containing arrowroot powder, cork fish, tempeh (fermented soybeans), nondairy creamer, and pumpkin, was performed in a nationally standardized Food Processing Technology Laboratory in Yogyakarta, Indonesia. The enteral formula was given twice a day for 3 consecutive weeks in addition to the patients' daily meal.

Statistical Analysis Nutritional indices before and after enteral nutrition supplementation were analyzed using $t$-test. All statistical analyses were at $5 \%$ significance level.

Results Of the 22 post-stroke patients, we used the cutoff point of National Institutes of Health Stroke Scale $\geq 3$ and Barthel Index $<90$ to represent dependency. Our findings showed significantly reduced mid-upper arm circumference and increased body mass index in independent post-stroke patients after the enteral nutrition supplementation. The tendency of increasing total cholesterol level should be carefully watched in dependent post-stroke patients.

Conclusion Local food-based enteral nutrition supplementation for 3 consecutive weeks in post-stroke patients may improve their nutritional status.

\section{Introduction}

Malnutrition is determined as a condition that leads to poor clinical outcome in many patients. ${ }^{1}$ Acute stroke and post-stroke patients are prone to malnutrition. ${ }^{2,3}$ Malnutrition status during hospital stay of acute stroke treatment is considered as an independent risk factor for developing complications, mortality, prolonged hospital length of stay, and medical costs after 6 months of post-stroke., ${ }^{4,5}$ In addition, more than 50\% stroke patients were discharged with malnourished status that is further complicated with dysphagia,
DOI https://doi.org/

10.1055/s-0040-1721202

ISSN 0976-3147. (c) 2021. Association for Helping Neurosurgical Sick People.

This is an open access article published by Thieme under the terms of the Creative Commons Attribution-NonDerivative-NonCommercial-License, permitting copying and reproduction so long as the original work is given appropriate credit. Contents may not be used for commercial purposes, or adapted, remixed, transformed or built upon. (https://creativecommons.org/licenses/by-nc-nd/4.0/)

Thieme Medical and Scientific Publishers Pvt. Ltd. A-12, 2nd Floor, Sector 2, Noida-201301 UP, India 
elderly, limited upper extremities movement, visuospatial disturbance, and depression. ${ }^{3}$

During hospital stay of acute stroke treatment, nutritional treatment becomes one of the wholistic approach to support the patient's care. The food products should be maintained for easy consumption and digestion as well as managed to fulfil the daily nutritional needs. Nutritional supplementation is given individually as necessary, for instance, dietary supplements with high protein, high essential fatty acids, high vitamin and mineral, or high-fiber content. A proper food and supplement's composition in the diet support a quick recovery as well as prevent the risk of developing disease's complications. ${ }^{6}$

However, malnutrition may still develop during adult patients' hospitalizations, regardless their nutritional status on the day of admission. ${ }^{7}$ Furthermore, the nutritional treatment for the post-stroke patient may be neglected after hospital discharge due to depression, poor family care, delayed rehabilitation, and history of malignancy or severe alcoholism. ${ }^{8,9}$ Therefore, simple nutritional preparation for post-stroke patients that is convenience for the caregivers should be considered.

Stroke, particularly acute ischemic stroke, is known to cause high catabolic signaling that leads to muscle wasting. ${ }^{10}$ Therefore, post-stroke patients need high energy, protein, and antioxidants, as well as other micronutrients in their daily dietary nutrition. Nowadays, special liquid food mixture containing macro- and micronutrients has been widely developed to include the available local food ingredients with reasonable price. ${ }^{11}$ We previously developed foodbased enteral nutrition from potential local food that widely grows in Indonesia. ${ }^{12}$ The use of this enteral formula is not only limited in the hospital but also at home.

In this study, we used the local-based enteral formula for nutritional supplementation of post-stroke patients to see its effects on the nutritional status based on the nutritional indices and laboratory parameters.

\section{Materials and Methods}

This is an experimental research with a pre- and post-test study design in a group of post-stroke patients without any control.

\section{Subjects of the Study}

Post-stroke patients who were the members of Indonesian Stroke Society (Yayasan Stroke Indonesia) in Yogyakarta, Indonesia, participated in this study. All post-stroke patients who participated in this study were confirmed eligible by their attending physician and met the inclusion criteria. The inclusion criteria for this study are post-stroke patients who were discharged from the hospital for at least 6 months and signed the informed consents. The exclusion criteria for this study are patients who were suffered from diabetes mellitus, chronic renal failure and allergic to any fish product. This study was approved by The Ethical Committee of Faculty of Medicine, Public Health, and Nursing, Universitas Gadjah Mada, Yogyakarta, Indonesia (No. KE/FK/0691/EC/2017).

\section{Enteral Nutrition Preparation}

We selected the following local foods for the main ingredients of the enteral nutrition: the arrowroot powder as energy source, cork fish (Channa striata), tempeh (locally-made fermented soybeans), and nondairy creamer as protein source, yellow pumpkin as fiber, vitamin, and mineral source, and low-glycemic index sugar. These ingredients were all collected from several local places, for instance, the arrowroot powder and tempeh were acquired from the local certified distributor in Yogyakarta, the fresh cork fish and yellow pumpkins were freshly obtained from the local farmer in Yogyakarta and Central Java, and other ingredients were purchased from the traditional market or supermarket in Yogyakarta.

The preparation of the enteral nutrition was performed as reported in our previous study. ${ }^{13}$ In brief, all ingredients were powdered, mashed using blender, and then filtered using pharmaceutical strainer. Nutrition content was analyzed in each powdered ingredient. The powder form of the ingredients was then calculated to contain $160.55 \mathrm{kcal}$ of energy, 8 $\mathrm{g}$ of protein, $4.6 \mathrm{~g}$ of fat, $22 \mathrm{~g}$ of carbohydrate, $3.8 \mathrm{~g}$ of total fiber, $12.8 \mathrm{ppm}$ of antioxidant activity, $0.03 \mathrm{QE} /$ gram flavonoid, and $0.08 \mathrm{mg}$ of phenol per serving. Each enteral nutrition serving was then packaged individually. The enteral nutrition preparation from fresh ingredients until individual packaging was performed in a nationally standardized Food Processing Technology Laboratory in Yogyakarta, Indonesia (Laboratorium Teknologi Proses Pangan Lokal LIPI, Yogyakarta, Indonesia).

\section{Enteral Nutrition Supplementation}

All study participants underwent clinical and laboratory examinations before and after the enteral nutrition supplementation. The following clinical parameters were measured: body mass index (BMI), mid-upper arm circumference (MUAC), and body fat percentage. The following laboratory parameters were examined: blood albumin level, blood urea level, blood creatinine level, blood hemoglobin level, fasting blood glucose level, total cholesterol, sodium, and potassium.

The enteral nutrition was supplemented twice a day for 3 consecutive weeks in addition to the patients' daily meal. A routine follow-up was performed weekly to ensure the patients' compliance, assess any allergic reactions, monitor the patients' nutritional indices, and perform counselling as needed. We considered the subjects as drop out if the enteral nutrition consumption was less than $75 \%$ in total for the indicated time period of 3 weeks.

\section{Statistical Analysis}

All data were expressed as mean \pm standard deviation, unless specified otherwise. The data homogeneity was analyzed using Kolmogorov-Smirnov normality test. Nutritional indices of the subjects before and after enteral nutrition supplementation were analyzed using $t$-test. The analyses were performed using SPSS version 14.0. All statistical analyses were at $5 \%$ significance level. 


\section{Results}

Of the 24 post-stroke patients who initially consented to follow the study, there were 22 patients who completed the study. Two post-stroke patients were excluded due to less than $75 \%$ consumption of the enteral nutrition supplementation and loss to follow-up. The data of these 22 post-stroke patients were included in further study analyses. Baseline characteristics of the subjects before they received enteral nutrition treatment were presented in - Table 1 .

We performed further data analysis according to the post-stroke patients' functional and severity scale to describe whether the post-stroke patients' dependency may give contrasting effect. We used the cut-off point of National Institutes of Health Stroke Scale (NIHSS) $\geq 3$ and Barthel index (BI) $<90$ to represent the dependent post-stroke patients

Table 1 Baseline characteristics of post-stroke patients before enteral nutrition supplementation

\begin{tabular}{|c|c|}
\hline Parameters & $\begin{array}{l}\text { Mean } \pm \text { SD } \\
(n=22)\end{array}$ \\
\hline Age (y) & $64.5909 \pm 7.8173$ \\
\hline \multicolumn{2}{|l|}{ Gender } \\
\hline \multicolumn{2}{|l|}{ Male, $n=20(90.9 \%)$} \\
\hline \multicolumn{2}{|l|}{ Female, $n=2(9.1 \%)$} \\
\hline \multicolumn{2}{|l|}{ Nutritional and clinical parameters } \\
\hline Height (cm) & $165.3182 \pm 5.49793$ \\
\hline Body weight (kg) & $67.7955 \pm 10.93437$ \\
\hline Body mass index (BMI) $\left(\mathrm{kg} / \mathrm{m}^{2}\right)$ & $24.7879 \pm 3.67662$ \\
\hline $\begin{array}{l}\text { Mid-Upper arm circumference } \\
\text { (MUAC) }(\mathrm{cm})\end{array}$ & $30.1273 \pm 3.63438$ \\
\hline Systolic blood pressure $(\mathrm{mm} \mathrm{Hg})$ & $141.2857 \pm 16.38030$ \\
\hline Diastolic blood pressure (mm Hg) & $89.9048 \pm 10.75130$ \\
\hline Body fat percentage (\%) & $26.4227 \pm 5.0129$ \\
\hline \multicolumn{2}{|l|}{ Stroke severity and functional score } \\
\hline $\begin{array}{l}\text { National Institutes of Health } \\
\text { Stroke Scale (NIHSS) }\end{array}$ & $2.1905 \pm 2.4823$ \\
\hline \multicolumn{2}{|l|}{ NIHSS $\geq 3(n=8,36.36 \%)$} \\
\hline Barthel Index & $92.381 \pm 16.0949$ \\
\hline \multicolumn{2}{|l|}{$\begin{array}{l}\text { Barthel Index }<90(n=4, \\
18.18 \%)\end{array}$} \\
\hline \multicolumn{2}{|l|}{ Laboratory parameters } \\
\hline Blood albumin level (g/dL) & $4.6409 \pm 0.2971$ \\
\hline Fasting blood glucose (mg/dL) & $93.2857 \pm 23.00683$ \\
\hline Blood urea level (mg/dL) & $32.2857 \pm 9.91031$ \\
\hline Blood creatinine level (mg/dL) & $1.2305 \pm 0.38011$ \\
\hline Blood uric acid level (mg/dL) & $6.6476 \pm 1.36184$ \\
\hline Total cholesterol level (mg/dL) & $189.5714 \pm 29.16431$ \\
\hline Blood sodium level (mmol/L) & $144.2381 \pm 1.48003$ \\
\hline Blood potassium level (mmol/L) & $4.2048 \pm 0.33982$ \\
\hline
\end{tabular}

Abbreviation: SD, standard deviation. with neurological deficit and functional outcome that may significantly affect the normal daily living activity.

In dependent post-stroke patients with NIHSS $\geq 3$, we found that total cholesterol level increased significantly after enteral nutrition supplementation. The mean total cholesterol level after the enteral nutrition supplementation was found to be slightly higher than the upper limit of normal cholesterol range. However, in post-stroke patients with NIHSS < 3, MUAC was found to be significantly declining (-Table 2A). In addition, the independent post-stroke patients showed the tendency of increased body weight and BMI.

According to the BI, dependent post-stroke patients whose $\mathrm{BI}<90$ showed no significant difference in any clinical, nutritional, and laboratory parameters. However, there is a tendency of increased total cholesterol level after the nutritional supplementation. However, in post-stroke patients with BI $\geq 90$, we found that their body weight and BMI significantly increased after routine scheduled enteral nutrition supplementation. The tendency of decreased MUAC was also found. In addition, this group showed increased blood creatinine level and decreased blood sodium level after the supplementation ( - Table 2B).

\section{Discussion}

In this study, we found that dependent post-stroke patients showed almost no change in nutritional indices both from clinical and laboratory parameters after 3 weeks enteral nutrition supplementation, except for a slight change in the increased total cholesterol level. In contrast, more independent post-stroke patients showed increase in body weight, BMI, and blood creatinine level; as well as decrease in MUAC and blood sodium level.

Although MUAC and BMI were two anthropometries used for assessing nutritional status, our findings showed contradictory results that more independent post-stroke patients showed decreased MUAC and increased BMI after enteral nutrition supplementation (-Table 2). Although the statistical analysis showed insignificant results, the dependent stroke patients also showed the tendency of decreased MUAC as well as increased BMI (-Table 2). However, MUAC and BMI mean values in both groups were still in the overweight range, ${ }^{13,14}$ before and after the enteral nutrition supplementation. Despite the positive and significant correlation between MUAC and BMI for assessing the nutritional status, several population studies showed that MUAC may be more accurate as a screening tool and predictive to measure outcome, especially in patients whose body height and weight were difficult to measure. ${ }^{15,16}$ Using MUAC as a more accurate screening tool, our findings may suggest that MUAC may be more readily affected compared with $\mathrm{BMI}$ in the improvement of nutritional status. However, longer period of follow-up is necessary for further assessment of the nutritional status in these patients.

From the laboratory parameters, our findings showed that more dependent post-stroke patients showed increased total cholesterol level after the enteral nutrition supplementation. 
Table 2 Clinical, nutritional, and laboratory parameters before and after enteral nutrition supplementation according to stroke functional and severity score

\begin{tabular}{|c|c|c|c|c|c|}
\hline \multicolumn{6}{|c|}{ A. According to NIHSS } \\
\hline \multirow[t]{2}{*}{ No. } & \multirow[t]{2}{*}{ Parameters } & \multicolumn{2}{|r|}{ NIHSS $<3(n=14)$} & \multicolumn{2}{|c|}{ NIHSS $\geq 3(n=8)$} \\
\hline & & Mean & $p$-Value & Mean & $p$-Value \\
\hline 1. & $\begin{array}{l}\text { Height }(\mathrm{cm}) \\
\text { Pre } \\
\text { Post }\end{array}$ & $\begin{array}{l}166.15 \\
166.15\end{array}$ & - & $\begin{array}{l}163.75 \\
163.75\end{array}$ & - \\
\hline 2. & $\begin{array}{l}\text { Body weight }(\mathrm{kg}) \\
\text { Pre } \\
\text { Post }\end{array}$ & $\begin{array}{l}68.32 \\
69.04\end{array}$ & 0.067 & $\begin{array}{l}68.16 \\
71.26\end{array}$ & 0.237 \\
\hline 3. & $\begin{array}{l}\text { BMI }\left(\mathrm{kg} / \mathrm{m}^{2}\right) \\
\text { Pre } \\
\text { Post }\end{array}$ & $\begin{array}{l}24.79 \\
25.04\end{array}$ & 0.065 & $\begin{array}{l}25.28 \\
26.57\end{array}$ & 0.254 \\
\hline 4. & $\begin{array}{l}\text { Mid-upper arm circumference } \\
\text { (cm) } \\
\text { Pre } \\
\text { Post }\end{array}$ & $\begin{array}{l}30.21 \\
29.36\end{array}$ & $0.029^{a}$ & $\begin{array}{l}30.18 \\
30.00\end{array}$ & 0.785 \\
\hline 5. & $\begin{array}{l}\text { Body fat percentage (\%) } \\
\text { Pre } \\
\text { Post }\end{array}$ & $\begin{array}{l}26.63 \\
25.71\end{array}$ & 0.299 & $\begin{array}{l}25.72 \\
25.95\end{array}$ & 0.323 \\
\hline 6. & $\begin{array}{l}\text { Systolic blood pressure }(\mathrm{mm} \mathrm{Hg}) \\
\text { Pre } \\
\text { Post }\end{array}$ & $\begin{array}{l}141.69 \\
143.23\end{array}$ & 0.818 & $\begin{array}{l}142.71 \\
145.00\end{array}$ & 0.520 \\
\hline 7. & $\begin{array}{l}\text { Diastolic blood pressure } \\
(\mathrm{mm} \mathrm{Hg}) \\
\text { Pre } \\
\text { Post }\end{array}$ & $\begin{array}{l}90.00 \\
89.00\end{array}$ & 0.754 & $\begin{array}{l}90.85 \\
90.42\end{array}$ & 0.811 \\
\hline 8. & $\begin{array}{l}\text { Fasting blood glucose }(\mathrm{mg} / \mathrm{dL}) \\
\text { Pre } \\
\text { Post }\end{array}$ & $\begin{array}{l}96.25 \\
94.67\end{array}$ & 0.664 & $\begin{array}{l}89.75 \\
9287\end{array}$ & 0.405 \\
\hline 9. & $\begin{array}{l}\text { Blood urea level }(\mathrm{mg} / \mathrm{dL}) \\
\text { Pre } \\
\text { Post }\end{array}$ & $\begin{array}{l}35.67 \\
33.41\end{array}$ & 0.286 & $\begin{array}{l}26.37 \\
29.87\end{array}$ & 0.303 \\
\hline 10. & $\begin{array}{l}\text { Blood creatinine level }(\mathrm{mg} / \mathrm{dL}) \\
\text { Pre } \\
\text { Post }\end{array}$ & $\begin{array}{l}1.29 \\
1.33\end{array}$ & 0.104 & $\begin{array}{l}1.07 \\
1.14\end{array}$ & 0.193 \\
\hline 11. & $\begin{array}{l}\text { Blood uric acid level }(\mathrm{mg} / \mathrm{dL}) \\
\text { Pre } \\
\text { Post }\end{array}$ & $\begin{array}{l}6.74 \\
6.90 \\
\end{array}$ & 0.638 & $\begin{array}{l}6.32 \\
6.68 \\
\end{array}$ & 0.370 \\
\hline 12. & $\begin{array}{l}\text { Total cholesterol level }(\mathrm{mg} / \mathrm{dL}) \\
\text { Pre } \\
\text { Post }\end{array}$ & $\begin{array}{l}189.33 \\
185.64\end{array}$ & 0.792 & $\begin{array}{l}195.00 \\
208.75\end{array}$ & $0.030^{\mathrm{a}}$ \\
\hline 13. & $\begin{array}{l}\text { Blood albumin level }(\mathrm{g} / \mathrm{dL}) \\
\text { Pre } \\
\text { Post }\end{array}$ & $\begin{array}{l}4.64 \\
4.70\end{array}$ & 0.305 & $\begin{array}{l}4.61 \\
4.77\end{array}$ & 0.365 \\
\hline 14. & $\begin{array}{l}\text { Blood sodium level }(\mathrm{mmol} / \mathrm{L}) \\
\text { Pre } \\
\text { Post }\end{array}$ & $\begin{array}{l}144.58 \\
143.00\end{array}$ & 0.095 & $\begin{array}{l}143.75 \\
143.87\end{array}$ & 0.903 \\
\hline 15. & $\begin{array}{l}\text { Blood potassium level }(\mathrm{mmol} / \mathrm{L}) \\
\text { Pre } \\
\text { Post }\end{array}$ & $\begin{array}{l}4.27 \\
4.25\end{array}$ & 0.824 & $\begin{array}{l}4.08 \\
4.08\end{array}$ & 1.000 \\
\hline
\end{tabular}

(Continued)

Although statistically insignificant, the independent poststroke patients may have the tendency of increased total cholesterol level after taking the enteral nutrition supplementation, particularly in patients whose $\mathrm{BI}$ were $\geq 90$ (-Table 2). We speculated that the increase in total cholesterol in dependent post-stroke patients may be affected by the lack of physical activities, particularly in elderly. On the other hand, the increased total cholesterol in independent stroke patients may be due to the uncontrolled diet. However, we did not record the daily dietary consumptions of the patients in this study other than the scheduled routine enteral formula twice a day. The increase cholesterol level as well as body fat accumulation may not be beneficial for post-stroke patients as hypercholesterolemia is a 
Table 2 (Continued)

\begin{tabular}{|c|c|c|c|c|c|}
\hline \multicolumn{6}{|c|}{ B. According to Barthel Index } \\
\hline \multirow[t]{2}{*}{ No. } & \multirow[t]{2}{*}{ Parameters } & \multicolumn{2}{|c|}{ Barthel Index < $90(n=4)$} & \multicolumn{2}{|c|}{ Barthel index $\geq 90(n=18)$} \\
\hline & & Mean & $p$-Value & Mean & p-Value \\
\hline 1. & $\begin{array}{l}\text { Height }(\mathrm{cm}) \\
\text { Pre } \\
\text { Post }\end{array}$ & $\begin{array}{l}162.50 \\
162.50\end{array}$ & - & $\begin{array}{l}165.94 \\
165.94\end{array}$ & - \\
\hline 2. & $\begin{array}{l}\text { Body weight }(\mathrm{kg}) \\
\text { Pre } \\
\text { Post }\end{array}$ & $\begin{array}{l}63.40 \\
68.86\end{array}$ & 0.338 & $\begin{array}{l}68.72 \\
69.51\end{array}$ & $0.014^{\mathrm{a}}$ \\
\hline 3. & $\begin{array}{l}\text { BMI }\left(\mathrm{kg} / \mathrm{m}^{2}\right) \\
\text { Pre } \\
\text { Post }\end{array}$ & $\begin{array}{l}23.73 \\
26.05\end{array}$ & 0.345 & $\begin{array}{l}25.02 \\
25.28\end{array}$ & $0.013^{\mathrm{a}}$ \\
\hline 4. & $\begin{array}{l}\text { Mid-upper arm circumference } \\
(\mathrm{cm}) \\
\text { Pre } \\
\text { Post }\end{array}$ & $\begin{array}{l}28.12 \\
27.50\end{array}$ & 0.492 & $\begin{array}{l}30.57 \\
30.01\end{array}$ & 0.130 \\
\hline 5. & $\begin{array}{l}\text { Body fat percentage }(\%) \\
\text { Pre } \\
\text { Post }\end{array}$ & $\begin{array}{l}25.05 \\
25.42\end{array}$ & 0.391 & $\begin{array}{l}26.56 \\
25.82\end{array}$ & 0.271 \\
\hline 6. & $\begin{array}{l}\text { Systolic blood pressure }(\mathrm{mm} \mathrm{Hg}) \\
\text { Pre } \\
\text { Post }\end{array}$ & $\begin{array}{l}142.75 \\
147.75\end{array}$ & 0.306 & $\begin{array}{l}140.94 \\
141.88\end{array}$ & 0.854 \\
\hline 7. & $\begin{array}{l}\text { Diastolic blood pressure } \\
\text { (mm } \mathrm{Hg}) \\
\text { Pre } \\
\text { Post }\end{array}$ & $\begin{array}{l}86.50 \\
87.50\end{array}$ & 0.391 & $\begin{array}{l}90.70 \\
89.52\end{array}$ & 0.636 \\
\hline 8. & $\begin{array}{l}\text { Fasting blood glucose }(\mathrm{mg} / \mathrm{dL}) \\
\text { Pre } \\
\text { Post }\end{array}$ & $\begin{array}{l}87.50 \\
90.00\end{array}$ & 0.639 & $\begin{array}{l}94.64 \\
94.76\end{array}$ & 0.968 \\
\hline 9. & $\begin{array}{l}\text { Blood urea level }(\mathrm{mg} / \mathrm{dL}) \\
\quad \text { Pre } \\
\text { Post }\end{array}$ & $\begin{array}{l}25.00 \\
28.50\end{array}$ & 0.271 & $\begin{array}{l}34.00 \\
32.41\end{array}$ & 0.473 \\
\hline 10. & $\begin{array}{l}\text { Blood creatinine level }(\mathrm{mg} / \mathrm{dL}) \\
\text { Pre } \\
\text { Post }\end{array}$ & $\begin{array}{l}1.00 \\
1.03\end{array}$ & 0.382 & $\begin{array}{l}1.28 \\
1.34\end{array}$ & $0.033^{\mathrm{a}}$ \\
\hline 11. & $\begin{array}{l}\text { Blood uric acid level }(\mathrm{mg} / \mathrm{dL}) \\
\text { Pre } \\
\text { Post }\end{array}$ & $\begin{array}{l}6.05 \\
6.30\end{array}$ & 0.206 & $\begin{array}{l}6.78 \\
7.02\end{array}$ & 0.421 \\
\hline 12. & $\begin{array}{l}\text { Total cholesterol level (mg/dL) } \\
\text { Pre } \\
\text { Post }\end{array}$ & $\begin{array}{l}207.50 \\
221.75\end{array}$ & 0.092 & $\begin{array}{l}185.35 \\
186.92\end{array}$ & 0.876 \\
\hline 13. & $\begin{array}{l}\text { Blood albumin level }(\mathrm{g} / \mathrm{dL}) \\
\text { Pre } \\
\text { Post }\end{array}$ & $\begin{array}{l}4.60 \\
4.75\end{array}$ & 0.547 & $\begin{array}{l}4.63 \\
4.69\end{array}$ & 0.487 \\
\hline 14. & $\begin{array}{l}\text { Blood sodium level }(\mathrm{mmol} / \mathrm{L}) \\
\text { Pre } \\
\text { Post }\end{array}$ & $\begin{array}{l}143.50 \\
144.50\end{array}$ & 0.630 & $\begin{array}{l}144.41 \\
143.00\end{array}$ & $0.040^{\mathrm{a}}$ \\
\hline 15. & $\begin{array}{l}\text { Blood potassium level }(\mathrm{mmol} / \mathrm{L}) \\
\text { Pre } \\
\text { Post }\end{array}$ & $\begin{array}{l}4.07 \\
4.10\end{array}$ & 0.854 & $\begin{array}{l}4.23 \\
4.24\end{array}$ & 0.916 \\
\hline
\end{tabular}

Abbreviation: NIHSS, National Institutes of Health Stroke Scale.

${ }^{a}$-Value $<0.05$

well-acknowledged stroke risk factor that may increase the occurrence of recurrent acute ischemic stroke. ${ }^{17,18}$ Other laboratory parameters that showed significant difference in this study were increased blood creatinine level and decreased blood sodium level in independent post-stroke patients after the enteral nutrition supplementation. However, their values were still within normal limit.

Although the results of this study may show promising results, there were several limitations that should be addressed: the little number of the subjects, the short period 
of follow-up to see the actual changes due to nutritional intake, the unrecorded data of the daily meal intake, the less variations of the subjects' nutritional status, the undocumented data of the comorbidities of the post-stroke patients, and the unrecorded daily physical activities of the patients to describe energy expenditure. Therefore, further study in the future needs to be conducted in a larger number of subjects as well as a more detailed recording of the patients' nutritional status, comorbidities, and physical activities.

\section{Conclusion}

Our findings showed that local food-based enteral nutrition supplementation for 3 consecutive weeks in post-stroke patients may improve nutritional indices in post-stroke patients. As for the laboratory parameters, the tendency of increasing total cholesterol level should be carefully watched.

\section{Authors' Contributions}

Ismail Setyopranoto did the conception and design, data analysis, obtained funding, and final approval of the article. Susetyowati performed the conception and design, administrative, technical, and logistic support, data collection and assembly. Lily Arsanti Lestari contributed in the conception and design, administrative, technical, and logistic support, data collection and assembly. Probosuseno did the provision of study material, critical revision of the article, data collection and assembly. Punik Mumpuni Wijayanti provided administrative, technical, and logistic support, and done data collection and assembly, data analysis. Mawaddah Ar Rochmah drafted the article, analyzed the data, and provided statistical expertise.

\section{Ethical Approval}

This study confirms the Declaration of Helsinki and was approved by The Ethical Committee of Faculty of Medicine, Public Health, and Nursing, Universitas Gadjah Mada, Yogyakarta, Indonesia (No. KE/FK/0691/EC/2017).

\section{Funding}

None.

\section{Conflict of Interest}

None declared.

\section{Acknowledgment}

The authors are indebted to the post-stroke patients and their caregivers who were willingly participated in this study. The authors would like to deliver the deepest gratitude to the Indonesian Stroke Society (Yayasan Stroke Indonesia) in Yogyakarta for facilitating the study, Andre Steffanus Panggabean, MD for assisting in the statistical analysis, and Mrs. Herni Astuti for assisting in the distribution of the enteral nutrition supplement.

\section{References}

1 Jensen GL, Mirtallo J, Compher C, et al; International Consensus Guideline Committee. Adult starvation and disease-related malnutrition: a proposal for etiology-based diagnosis in the clinical practice setting from the International Consensus Guideline Committee. JPEN J Parenter Enteral Nutr 2010; 34(2):156-159

2 Mosselman MJ, Kruitwagen CL, Schuurmans MJ, Hafsteinsdóttir TB. Malnutrition and risk of malnutrition in patients with stroke: prevalence during hospital stay. J Neurosci Nurs 2013;45(4):194-204

3 Lieber AC, Hong E, Putrino D, Nistal DA, Pan JS, Kellner CP. Nutrition, energy expenditure, dysphagia, and self-efficacy in stroke rehabilitation: a review of the literature. Brain Sci 2018; 8(12):21810.3390/brainsci8120218

4 Martineau J, Bauer JD, Isenring E, Cohen S. Malnutrition determined by the patient-generated subjective global assessment is associated with poor outcomes in acute stroke patients. Clin Nutr 2005;24(6):1073-1077

5 Gomes F, Emery PW, Weekes CE. Risk of malnutrition is an independent predictor of mortality, length of hospital stay, and hospitalization costs in stroke patients. J Stroke Cerebrovasc Dis 2016;25(4):799-806

6 Poulsen I, Petersen HV, Hallberg IR, Schroll M. Lack of nutritional and functional effects of nutritional supervision by nurses: a quasi-experimental study in geriatric patients. Scand J Food Nutr 2007;51(1):6-12

7 Braunschweig C, Gomez S, Sheean PM. Impact of declines in nutritional status on outcomes in adult patients hospitalized for more than 7 days. J Am Diet Assoc 2000;100(11):1316-1322, quiz 1323-1324

8 Yang JS, Wang SS, Zhou XY, et al. [The risk factors for malnutrition in post-stroke patients.]. Zhonghua Nei Ke Za Zhi 2009; 48(12):1016-1018

9 Chen N, Li Y, Fang J, Lu Q, He L. Risk factors for malnutrition in stroke patients: A meta-analysis. Clin Nutr 2019;38(1):127-135

10 Springer J, Schust S, Peske K, et al. Catabolic signaling and muscle wasting after acute ischemic stroke in mice: indication for a stroke-specific sarcopenia. Stroke 2014;45(12):3675-3683

11 Gaboulaud V, Dan-Bouzoua N, Brasher C, Fedida G, Gergonne B, Brown V. Could nutritional rehabilitation at home complement or replace centre-based therapeutic feeding programmes for severe malnutrition? J Trop Pediatr 2007;53(1): 49-51

12 Lestari LA, Setyopranoto I, et al. Potential of local food-based enteral nutrition to improve patient's nutrition status in hospital in Yogyakarta, Indonesia.J Food Nutr Res 2019;7(8):568-572

13 Das A, Saimala G, Reddy N, et al. Mid-upper arm circumference as a substitute of the body mass index for assessment of nutritional status among adult and adolescent females: learning from an impoverished Indian state. Public Health 2020;179: 68-75

14 Benítez Brito N, Suárez Llanos JP, Fuentes Ferrer M, et al. Relationship between mid-upper arm circumference and body mass index in inpatients. PLoS One 2016;11(8): e016048010.1371/journal.pone.0160480

15 Powell-Tuck J, Hennessy EM. A comparison of mid upper arm circumference, body mass index and weight loss as indices of undernutrition in acutely hospitalized patients. Clin Nutr 2003;22(3):307-312

16 Nowak-Szczepanska N, Gomula A, Koziel S. Mid-upper arm circumference and body mass index as different screening tools of nutritional and weight status in Polish schoolchildren across socio-political changes. Sci Rep 2019;9(1):12399 10.1038/s41598-019-48843-5

17 Amarenco P. Hypercholesterolemia, lipid-lowering agents, and the risk for brain infarction. Neurology 2001;57(5, Suppl 2) : S35-S4410.1212/WNL.57.suppl_2.S35

18 Menet R, Bernard M, ElAli A. Hyperlipidemia in stroke pathobiology and therapy: insights and perspectives. Front Physiol 2018;9:48810.3389/fphys.2018.00488 